\title{
STUDIES ON EXPERIMENTAL PHOSGENE POISONING. III. OXYGEN THERAPY IN PHOSGENE-POISONED DOGS AND RATS ${ }^{1}$
}

\author{
By H. D. BRUNER, ROBERT D. BOCHE, CHARLES C. CHAPPLE, MARY H. GIBBON, \\ AND MILES D. MCCARTHY
}

(From the Harrison Department of Surgical Research, Schools of Medicine, University of Pennsylvania, Philadelphia)

(Received for publication February 11, 1947)

Clinical opinion of the value of inhalational oxygen therapy in "lung irritant" casualties in the first World War was uniformly high (1 to 4). The use of oxygen in subsequent accidental poisonings has confirmed that evaluation (5 to 12) and led to extension of the original views to pure phosgene poisoning. The relief usually afforded the patient appears to have been impressive. Objective improvement consisted of disappearance of the cyanosis and clearing of the sensorium; the tachycardia was sometimes relieved, but the dyspnea generally was not (2). Therapy with 100 per cent oxygen has been reported to reduce cough and relieve the sensation of a constricted chest $(8,9)$. For these reasons, oxygen therapy is the chief measure prescribed for phosgene poisoning in official manuals and treatises on this subject. Further substantiation is necessary for other claimed benefits of oxygen therapy, such as inhibiting the development of severe edema, shortening the duration of illness, and diminishing dilatation of the right side of the heart $(1,8,13,14)$.

While it is generally agreed that oxygen therapy is clinically indicated in this type of pulmonary edema, no data have been found which permit statistical confirmation of the ultimate benefits of such therapy. A close examination of the literature brought out the following: (a) The clinical prognosis must have been the basis for claims of its life-saving value, but experience with poisoned animals has shown the fallibility of prognosis. (b) The average mortality attributable to phosgene in the A. E. F. of World War I was very low, less than 2.5 per cent of gas casualties (15). This low mortality rate automatically emphasized symptomatic relief rather than survival as the criterion

1 The work described in this paper was done under a contract recommended by the Committee on Medical Research, between the Office of Scientific Research and Development and the University of Pennsylvania. of value. (c) At the time when the original observations were made, oxygen was administered by methods the best of which (Haldane's reservoir mask) provided concentrations of less than 60 per cent; the nasal catheter and funnel-over-theface techniques were commonly used and the regimen varied from a few breaths at intervals to continuous use for symptomatic relief of cyanosis (1 to 3). (d) The true value of oxygen therapy in phosgene casualties is difficult to assess because it was but one of several drugs or procedures employed. (e) In accidental poisonings, deaths have been recorded despite apparently effective methods of oxygen administration $(10,11)$.

The previously reported data on oxygen therapy of experimentally poisoned animals contradict the clinical evaluation. Underhill (16) found that survival of poisoned dogs was not significantly improved by residence in 50 per cent oxygen for the first 72 hours after gassing, although symptomatically the dogs seemed better and the arterial and venous oxygen saturations were temporarily raised. Meek and Eyster (17) noted that the majority of an unspecified number of dogs lived 48 to 72 hours in 40 to 60 per cent oxygen, instead of the average of 16 hours in air. Dumoulin and Charlier (18) reported that 50 per cent oxygen did not increase the survival of phosgene-poisoned rats, while continuous stay in 90 per cent oxygen resulted in a still higher ultimate mortality. Soulie (19) confirmed these results and emphasized the similarity of survival rates during the first 24 hours of treatment, during which oxygen poisoning is unlikely.

Additional information was therefore necessary as to whether oxygen therapy improved the survival rate in phosgene poisoning and, if so, what were the optimum conditions of administration. Because omission of therapy in accidental poison- 
ing might lead to loss of life, the problem was necessarily studied in animals, although it was recognized that the pathologic physiology and resistance to anoxia in the dog and rat might differ from that of man. The main experiments were patterned after Underhill's (16), using an L(CT) 60 to 80 of phosgene. This mortality was chosen as being most favorable for demonstrating a beneficial effect from oxygen therapy. Additional experiments with low oxygen tensions were carried out to test the possibility discussed by Drinker (20) that anoxia might contribute to the development of pulmonary edema, or further it in the sense of a vicious circle.

\section{MATERIALS AND METHODS}

The dogs were healthy adult mongrels, weighing 6 to $12 \mathrm{kgm}$., used after an isolation period had shown them to be free of respiratory infection. The rats were young adults, obtained directly from the Wistar Institute. The dogs in fours or sixes were exposed to a mixture of air and pure phosgene in a 850-liter gassing chamber, operated dynamically at a flow of 800 liters per minute. The mean concentration of phosgene and standard deviation were $0.275 \pm 0.0045 \mathrm{mgm}$. per liter by analysis, and the duration of exposure was 30 minutes. The rats were similarly gassed in groups of 20 or 40 , but for the shorter time required to give the desired mortality. Selection of gassed animals for oxygen therapy was by lottery.

Oxygen therapy was administered to the dogs by keeping them in a closed chamber of 964 liters capacity, the atmosphere of which circulated at the rate of 935 liters per minute. During circulation the atmosphere passed over a cooling radiator at $0^{\circ} \mathrm{C}$., and trays of soda-lime and $\mathrm{CaCl}_{2}$ in that order. By frequent sampling or automatic regulation the atmosphere was controlled to the following levels : (a) Humidity was less than $\mathbf{4 0}$ per cent, average 32 to 34 per cent. (b) $\mathrm{CO}_{2}$ was less than 0.5 per cent, average about 0.2 per cent by Haldane analyzer. (c) Temperature was room temperature $\pm 5^{\circ} \mathrm{F}$. (d) The oxygen concentration, determined by the Scholander-Roughton method or the Pauling meter, was put up by flushing the chamber with oxygen to the desired level, which then was maintained by a Pitot type injector system. Inflow of oxygen or oxygen-air was in large excess of the requirements of the animals. Three concentrations of oxygen were employed, 95 per cent, 80 per cent, and 40 per cent. ${ }^{2}$

Six or 8 gassed dogs, depending on size, were placed in the chamber and kept there until death, or for 72 hours. Oxygen therapy was not begun until all the animals of an experiment had been gassed and hence with

2 A large seriej of phosgene-poisoned dogs treated with 60 per cent oxygen was studied by another group elsewhere and will be reported separately. different animals there was an interval of 20 minutes to $21 / 2$ hours between the end of gassing and beginning of oxygen therapy. At the end of 72 hours in oxygen the survivors were brought immediately into room air. By means of sleeved ports which permitted access into the chamber without loss of oxygen concentration, hematocrit determinations, heart rate, respiratory rate, and other clinical observations were made routinely. The animals were supplied with water, Purina checkers, and a protein digest in water at all time. Dead animals were removed from the chamber for immediate autopsy. In 2 experiments gassed rats were placed in barricaded cages in the oxygen chamber with the dogs given 95 per cent oxygen therapy.

Experiments on rats in low oxygen mixtures were carried out using either a 67-liter chamber, or the large chamber; both were operated dynamically by means of a continuous inflow of mixtures of air, nitrogen, and carbon dioxide at rates of 2 to 5 liters per minute. The rats were placed in these chambers at once after gassing and kept there for varying periods. They were unrestricted and had access to food and water. The controls remained in similar cages in room air in most experiments, but in 2 experiments the factor of air movement over the rats was controlled by placing the gassed controls in another similar chamber and passing air through it.

\section{Oxygen toxicity control studies}

In view of the probability that oxygen poisoning might be superimposed on phosgene poisoning when 80 per cent and 95 per cent oxygen were used, a series of experiments was designed to assess the effect of oxygen alone.

Three of 21 normal dogs died after 47 to 48 hours in 95 per cent oxygen, while 4 more died after $52,59,63$, and 89 hours in this atmosphere. One animal survived 116 hours and when sacrificed after 1 hour in room air showed only slight pulmonary edema and congestion, although markedly dyspneic. This dog contrasts with another which died an acute anoxic death upon being removed from the oxygen chamber after 48 hours. Eleven of the 21 dogs were sacrificed at the end of 48 hours in oxygen; these animals showed edema of the larynx, some pulmonary congestion, and minimal pulmonary edema; and the lung-to-body weight ratios were slightly beyond the upper limits of normal. One dog lived indefinitely following 48 hours residence in 95 per cent oxygen.

Eight dogs were confined in 80 per cent oxygen for 72 hours and none died. Four, sacrificed at the end of that period, showed mild pulmonary congestion and slight pulmonary edema, and the lung-to-body weight ratios again were at the upper limits of normal. The remaining 4 dogs survived without apparent difficulty.

Adult rats appeared to show somewhat greater susceptibility to oxygen poisoning; 18 of 20 rats died after 36 to 65 hours in 95 per cent oxygen; 1 died on removal from the chamber and only 1 survived 72 hours residence.

These data emphasize the high degree of individual susceptibility to 95 per cent oxygen, and are in agree- 
ment with the findings of others $(19,21)$. The general physiologic characteristics of oxygen poisoning noted in recent reviews by Bean (22) and Stadie (23) were observed in these experiments.

The lungs of oxygen-poisoned animals resemble liver in appearance and consistency, and drip fluid on section; the histologic picture resembles that of phosgene poisoning rather closely (24). Inflating such lungs brings out the emphysema, and grossly they then resemble phosgenepoisoned lungs rather than liver. In most instances the degree of lung damage was poorly correlated with clinical appearance and respiratory distress.

No control experiments were carried out with 40 per cent oxygen, as the series with 80 per cent oxygen, although small, showed no lethal effects. This latter series also served as a control for conditions of residence in the chamber.

\section{RESULTS}

The survival curves of the 3 series of experiments on dogs are shown in Figures 1, 2, and 3; the number of dogs in the control and experimental groups are shown in each figure. Attention is directed to the deaths occurring shortly after removal from the atmospheres of 95 and 80 per cent oxygen. These animals died with signs of acute anoxia in room air, whereas in the oxygen-enriched atmospheres they had not been cyanotic, despite dyspneic breathing. A detailed statistical analysis of the data makes the following statements probable:

\section{Effect of $95+\% \quad O_{2}$ on Survival}

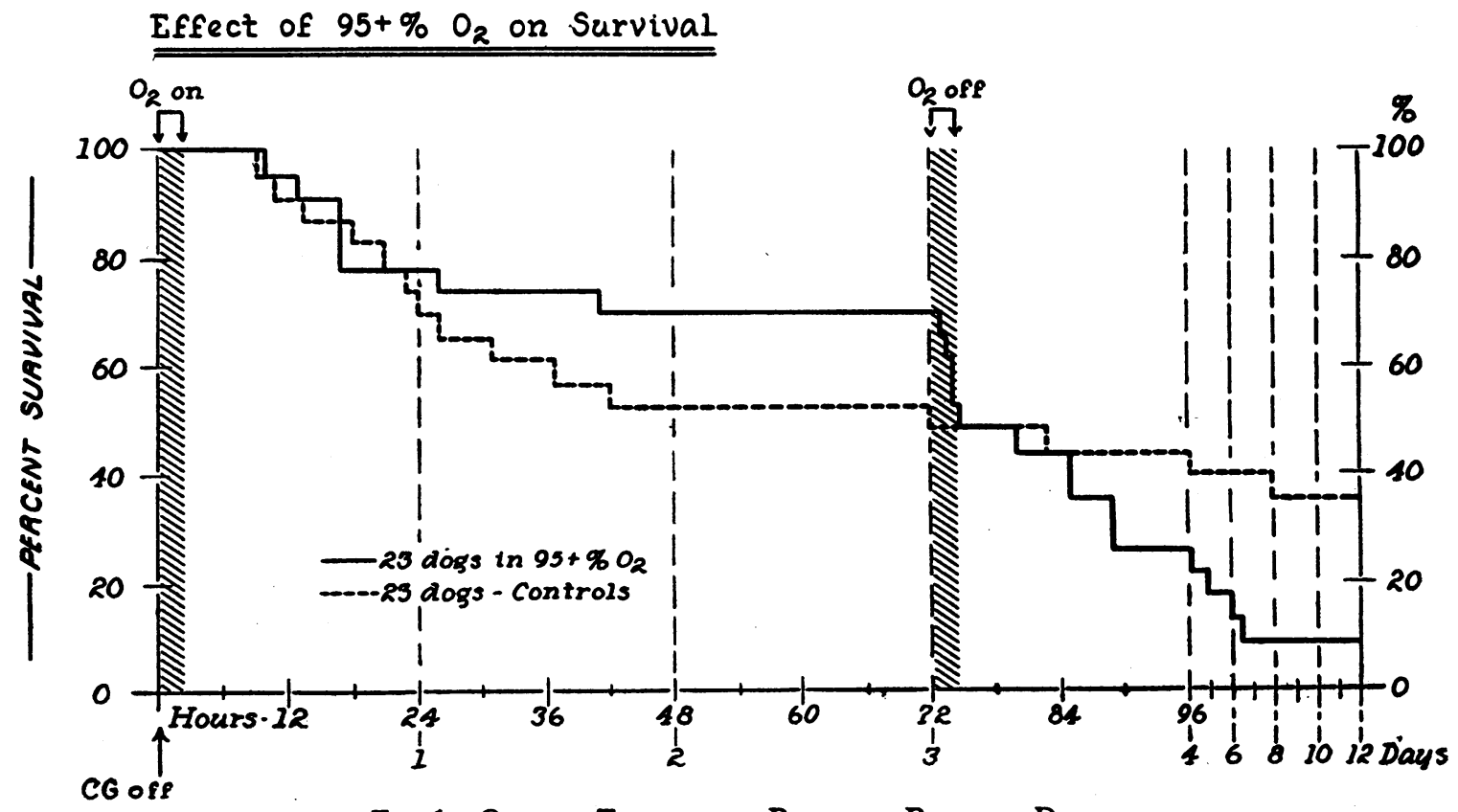

Fig. 1. Oxygen Therapy in Phosgene-Poisoned Dogs
1. According to Fisher's test for homogeneity (25) the 3 control series are comparable one with another and form a homogeneous set of data; therefore, they may be grouped together. This is true regardless of the time at which survival numbers are taken, i.e., the percent survivals at $1,2,3$, and 10 days are essentially the same in the 3 control groups. The number of delayed deaths in the controls for the 95 per cent series was somewhat unusual, but this does not alter the statistical homogeneity.

2. Comparison of the 95 per cent oxygen series with the grouped controls failed to show à very significant increase in survival at 24 hours $(P=$ 0.057 , Fisher's exact method) but did show a significant improvement at 2 days $(P=0.03)$ and 3 days $(P=0.02)$. The ultimate survival, based on that of the tenth day, was significantly decreased $(P=0.02)$ by treatment with 95 per cent oxygen when administered as described above.

3. Comparison of the 80 per cent oxygen series with the grouped controls showed that survival was not improved on a 1-, 2-, or 3-day basis, and that the ultimate, or 10-day, survival was significantly decreased $(P=0.03)$.

4. Comparison of the 40 per cent oxygen series with the grouped controls shows that this concen- 


\section{Effect of $80 \% \mathrm{O}_{2}$ on Survival}

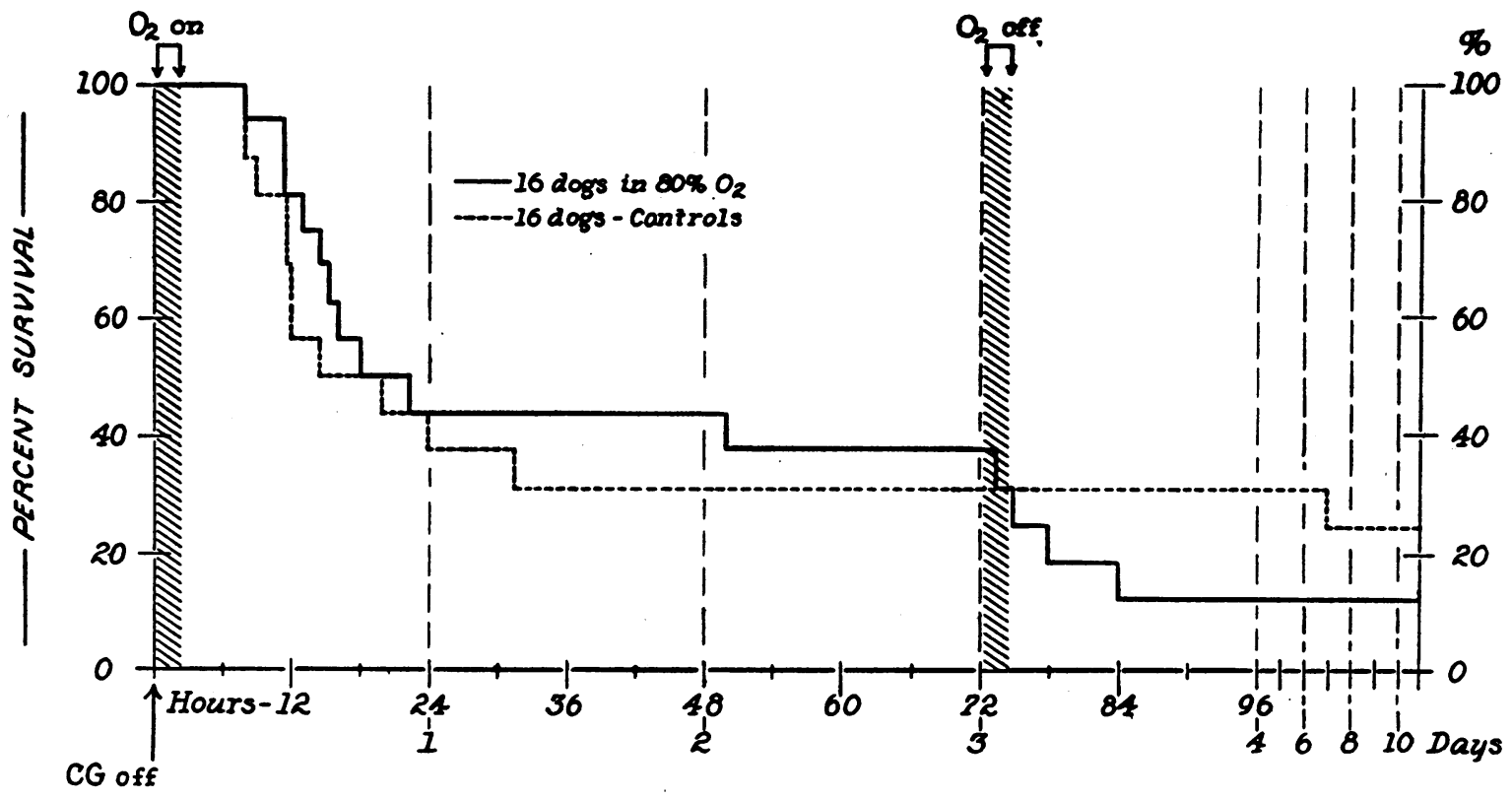

Fig. 2. Oxygen Therapy in Phosgene-Poisoned Dogs

\section{Effect of $40 \% \mathrm{O}_{2}$ on Survival}

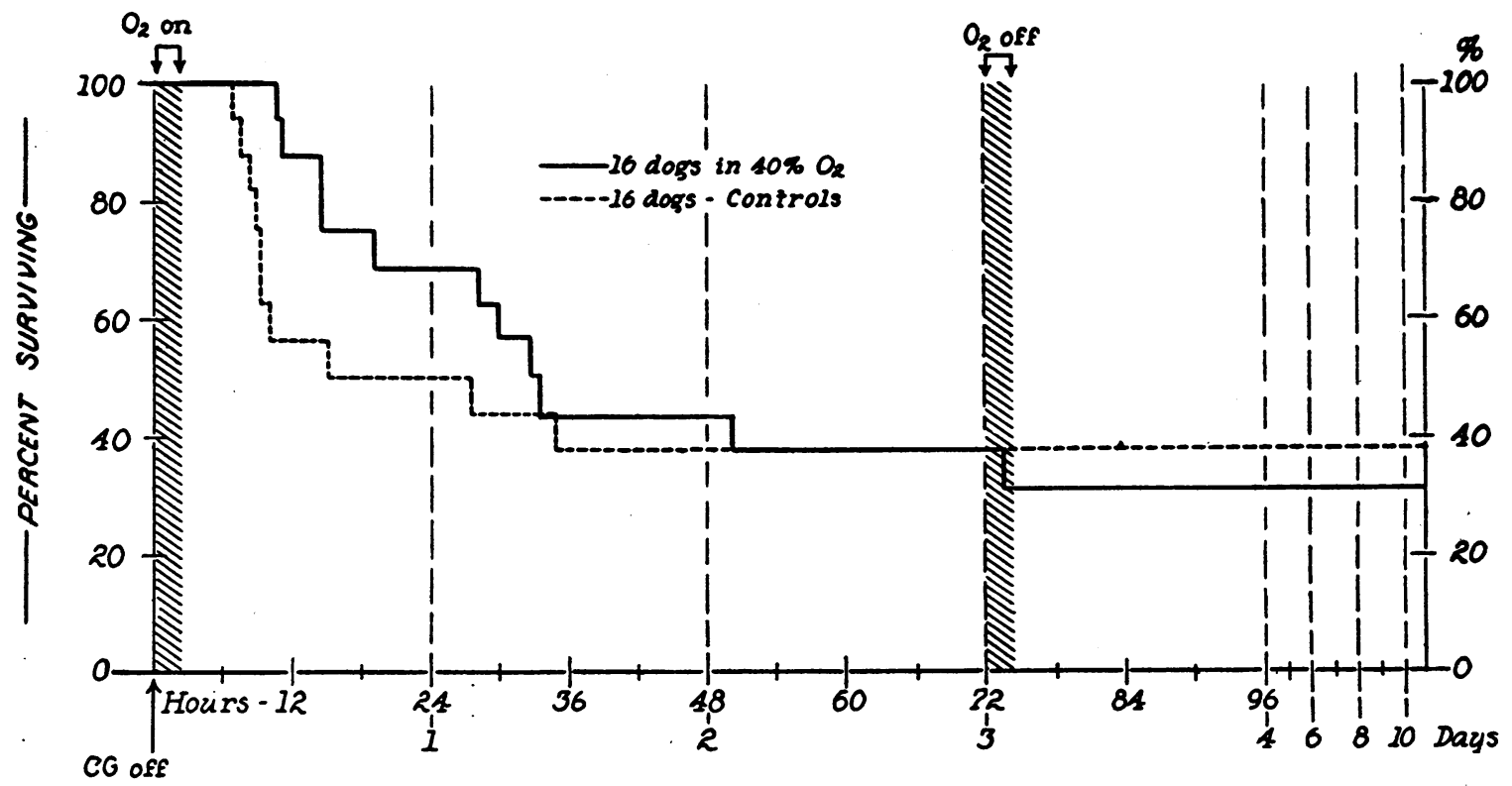

Fig. 3. Oxygen Therapy in Phosgene-Poisoned Dogs 
tration of oxygen did not significantly influence either immediate or ultimate survival.

While the numbers of animals in each of the treated groups are comparatively small, the statistical analysis is supported by its agreement with the interpretations gained by inspection of the survival curves.

Judged by the responsiveness of the animals, their appetite, and the rate, depth, and ease of breathing, those treated with 40 per cent oxygen appeared to be in better clinical condition throughout than the controls, even up to the immediate premortem phase. In 80 per cent and 95 per cent oxygen this improvement was noted only during the first 36 to 48 hours; thereafter, the survivors appeared worse clinically than the controls living in room air. The surviving controls by this time gave clinical evidence of having passed the critical period.

No relation was found between the length of survival and the interval between gassing and beginning oxygen therapy. No effect of oxygen therapy was found on the rate of development of pulmonary edema as judged by the rate of hemoconcentration. The degree of edema at death (within 80 hours) was essentially the same for both groups, the treated animals having an average lung-to-body weight ratio of 4.1 and the control group an average of 4.2 . The heart rate tended throughout to be slower in the oxygen-treated animals than in the controls. Bradycardia was found in normal animals residing in oxygen concentrations of 80 per cent or above.

At autopsy, gassed animals that had died in the 95 per cent oxygen, or within 1 or 2 hours after removal into room air, showed the liver-like lung of oxygen poisoning, but forced inflation of the lung restored the typical picture of phosgene poisoning. In the 80 per cent oxygen series, a few emphysematous blebs were present at death, while in the 40 per cent oxygen series the lungs were like those of typical phosgene poisoning; the latter was also true of the dogs of the 80 per cent and 95 per cent series which died 4 hours or longer after being returned to air.

The survival of 20 phosgene-poisoned rats was similarly unimproved by 95 per cent oxygen treatment. Their autopsy findings were like those described for dogs.
It was impossible to determine from either gross or histologic examination of the lungs and other tissues how oxygen therapy had influenced the course of phosgene poisoning, or whether oxygen poisoning had been superimposed on the phosgene poisoning. The pulmonary damage by the 2 agents is so similar as to defeat pathological methods of differentiation (24).

Five phosgene-poisoned rats were kept for 48 hours in 100 per cent oxygen maintained at $1 / 2$ atmosphere, a condition which was proved not to produce oxygen poisoning in normal animals. The lungs of these rats were solid and liver-like; hence, the anatomic appearance of the lung after high oxygen therapy may be attributed to the absence of an inert gas and not to high oxygen tensions per se. This form of oxygen therapy also failed to lower the mortality rate.

Data on the mortality following residence in low oxygen tensions for 1 and 4 hours after gassing are shown in Table I. It is evident that this procedure did not increase the mortality of phosgene-poisoned rats, and comparison by the $\chi^{2}$

TABLE I

Survival of phosgene-poisoned rats following residence in low oxygen atmospheres* during the early phases of poisoning

\begin{tabular}{|c|c|c|c|c|c|c|}
\hline \multirow{2}{*}{$\begin{array}{l}\text { Dose of } \\
\text { phosgene }\end{array}$} & \multirow{2}{*}{ Procedure } & \multirow{2}{*}{$\begin{array}{l}\text { No. of } \\
\text { rats }\end{array}$} & \multirow{2}{*}{$\begin{array}{l}\text { Hours } \\
\text { in low } \\
\text { oxygen }\end{array}$} & \multirow{2}{*}{$\begin{array}{c}\text { Aver- } \\
\text { age } \\
\text { oxygen } \\
\text { level }\end{array}$} & \multicolumn{2}{|c|}{$\begin{array}{l}\text { Rats surviving } \\
\text { at: }\end{array}$} \\
\hline & & & & & $\begin{array}{c}24 \\
\text { hours }\end{array}$ & $\begin{array}{c}72 \\
\text { hours }\end{array}$ \\
\hline$\underset{\text { per liter }}{\operatorname{mgm} . \min }$ & & & & $\begin{array}{l}\text { per } \\
\text { cent }\end{array}$ & \multicolumn{2}{|c|}{ per cent } \\
\hline 2.32 & $\begin{array}{l}\text { Treated } \\
\text { Treated } \\
\text { Controls }\end{array}$ & $\begin{array}{r}5 \\
5 \\
10\end{array}$ & $\begin{array}{l}1 \\
4\end{array}$ & $\begin{array}{l}10.6 \\
10.6\end{array}$ & $\begin{array}{l}60 \\
80 \\
20\end{array}$ & $\begin{array}{l}60 \\
80 \\
20\end{array}$ \\
\hline 2.90 & $\begin{array}{l}\text { Treated } \\
\text { Treated } \\
\text { Controls }\end{array}$ & $\begin{array}{r}5 \\
5 \\
10\end{array}$ & $\begin{array}{l}1 \\
4\end{array}$ & $\begin{array}{l}10.7 \\
12.2\end{array}$ & $\begin{array}{l}60 \\
60 \\
50\end{array}$ & $\begin{array}{l}40 \\
60 \\
50\end{array}$ \\
\hline 2.38 & $\begin{array}{l}\text { Treated } \\
\text { Treated } \\
\text { Controls }\end{array}$ & $\begin{array}{r}5 \\
5 \\
10\end{array}$ & $\begin{array}{l}1 \\
4\end{array}$ & $\begin{array}{l}10.8 \\
11.8\end{array}$ & $\begin{array}{l}60 \\
60 \\
70\end{array}$ & $\begin{array}{l}20 \\
60 \\
70\end{array}$ \\
\hline 1.61 & $\begin{array}{l}\text { Treated } \\
\text { Controls }\end{array}$ & $\begin{array}{l}10 \\
10\end{array}$ & 4 & 10.8 & $\begin{array}{l}80 \\
60\end{array}$ & $\begin{array}{l}70 \\
60\end{array}$ \\
\hline 1.54 & $\begin{array}{l}\text { Treated } \\
\text { Controls** }\end{array}$ & $\begin{array}{l}10 \\
10\end{array}$ & 3 & 12.5 & $\begin{array}{l}90 \\
60\end{array}$ & $\begin{array}{l}90 \\
60\end{array}$ \\
\hline 1.69 & $\begin{array}{l}\text { Treated } \\
\text { Controls** }\end{array}$ & $\begin{array}{l}10 \\
10\end{array}$ & 4 & 13.0 & $\begin{array}{l}70 \\
60\end{array}$ & $\begin{array}{l}70 \\
50\end{array}$ \\
\hline
\end{tabular}

* $\mathrm{CO}_{2}$ was 0.25 per cent or less; humidity and temperature equal to room air.

** Controls kept in similar 67-liter chamber with room air circulating. 
test of the summed survivals of the rats treated for 4 hours, with their summed controls gives a $P$ value of slightly less than 0.03 , i.e., a probably significant reduction of mortality. This, however, is not fully representative of the remaining $13 \mathrm{ex}-$ periments, using 300 rats, in which oxygen percentage was varied between 10 and 18 per cent, $\mathrm{CO}_{2}$ between 0.25 and 5 per cent, humidity between 35 and 100 per cent, and duration of treatment between 1 and 4 hours, beginning at once after gassing. In these latter experiments the data were ambiguous in the sense that consistent, repeatable results could not be obtained; some experiments gave decidedly favorable survival rates in the treated groups, whereas others gave equally unfavorable survival rates. In short, it appears that treatment with low oxygen tensions in this way was not deleterious; whether it was beneficial is uncertain. Variations in factors other than oxygen percentage appeared not to influence the results.

The rats in the low oxygen tensions experienced anoxia, as judged by the respiratory efforts, the color of their ears and retina, and their behavior; when they were removed from the chamber after 4 hours they had palpable rales. No animals remained in the low oxygen atmospheres longer than 4 hours, a time at which edema generally was about half maximal. The lung-to-body weight ratios of many of the rats which died a few hours after being returned to room air were low compared with the controls.

\section{DISCUSSION}

The data show that while continuous 95 per cent oxygen therapy delayed death after gassing, it failed to improve ultimate survival. In fact, 95 per cent oxygen therapy as administered to gassed dogs had an adverse effect on ultimate survival, due presumably to superimposed oxygen toxicity. This finding is not peculiar to the dog, according to the reports of Dumoulin and Charlier (18) and Soulie (19). It therefore assumes clinical importance, first because high concentrations of oxygen, administered for long periods, were required to banish cyanosis in phosgene casualties of World War I (1), and, second, modern techniques of oxygen therapy are capable of providing oxygen tensions which might lead to oxygen poisoning.
Thus it would be unwise to administer oxygen tensions in excess of those necessary to saturate the hemoglobin. It is not reasonable to assume that unavoidable interruptions are a factor of safety in the so-called 100 per cent oxygen therapy by mask (26).

Although the data suggest that oxygen poisoning was superimposed on the phosgene poisoning, it is not possible to be certain of this at present. No differentiation could be made by either the histologic or physiologic methods used (24). Apparently, both induce similar if not identical pulmonary reactions and produce death by the same process, but oxygen at inhaled tensions of 600 to 760 $\mathrm{mm}$. $\mathrm{Hg}$ requires a longer time factor. The wide variations in susceptibility to oxygen poisoning provide another important but unassessable consideration. A possible interpretation is that high tension oxygen therapy, by delaying death, permits accumulation of edema fluid in amounts greater than that which would have induced fatal anoxia in air; this extra fluid may then nullify therapy. The essential question must remain open for the present: Will high oxygen tensions administered to a lung damaged by phosgene give rise to processes which ultimately are just as lethal as the primary damage?

The data above suggest that oxygen therapy does little to prevent or break up the compound vicious cycle associated with the 2 forms of anoxia identified in phosgene poisoning: $(a)$ an anoxic anoxia, dependent on the pulmonary edema, and (b) a stagnant anoxia arising from the shock-like hemodynamics connected with reduced blood volume and increased blood viscosity. Oxygen therapy alone may relieve the anoxic anoxia and improve cardiac action without materially improving the general capillary circulation. Yet attempts to improve the circulation by infusions during oxygen therapy have not been successful (27).

It does not follow that every case of phosgene poisoning presents this gloomy outlook. It is reasonable to anticipate that an unknown but probably small proportion of cases would die during the phase of maximal edema if not supported by oxygen therapy. This possibility should not be disregarded in the clinical management of the single case, statistics notwithstanding. On the other hand, the above data justify use of the alternate case method in assessing clinically the value of 
oxygen therapy in the event of a mass exposure. The effects of sublethal anoxia on other tissues such as the kidney $(28,29)$, whose function is required during the subsequent restorative processes, indicate the use of oxygen. If it minimizes these later extra-pulmonary derangements, it is worthwhile.

While recognizing the mutual conflicts in the foregoing discussion, we nevertheless believe both points of view justified. However, it must be emphasized that a lessened ultimate mortality should be considered the only definitive criterion of benefit.

Drinker (20) recently proposed that anoxia of the pulmonary capillaries may cause, or exaggerate, edema initiated by other agents. This hypothesis might apply to phosgene poisoning, for blood oxygen analyses of gassed dogs show an anoxic and a stagnant anoxia present shortly after gassing (30) (Table II). This is also true of dogs

TABLE II

Average and range of oxygen saturations of arterial and venous blood of dogs poisoned by an $L(C T) 99$ of phosgene

\begin{tabular}{|c|c|c|c|}
\hline Oxygen saturation & $\begin{array}{c}\text { Before } \\
\text { gassing } \\
\text { (8 exps.) }\end{array}$ & $\begin{array}{l}15 \text { to } 20 \\
\text { minutes } \\
\text { after } \\
\text { gassing } \\
\text { (8 exps.) }\end{array}$ & $\begin{array}{l}2 \text { to } 5 \\
\text { hours } \\
\text { after } \\
\text { gassing } \\
\text { (5 exps.) }\end{array}$ \\
\hline $\begin{array}{l}\text { Arterial } \\
\text { oxygen } \\
\text { saturation }\end{array}$ & $\begin{array}{c}96 \\
(94-99)\end{array}$ & $\begin{array}{c}\text { per cent } \\
82 \\
(58-93)\end{array}$ & $\begin{array}{c}80 \\
(68-90)\end{array}$ \\
\hline $\begin{array}{l}\text { Venous } \\
\text { oxygen } \\
\text { saturation }\end{array}$ & $\begin{array}{c}62 \\
(37-91)\end{array}$ & $\begin{array}{c}21 \\
(11-84)\end{array}$ & $\begin{array}{c}26 \\
(16-47)\end{array}$ \\
\hline
\end{tabular}

poisoned by lower doses of phosgene (16). Generally, there is a partial recovery of normal saturation which is again reversed about the time edema becomes clinically detectable. It was noted that the more severe the immediate anoxemia, the sooner the animals died. Barcroft (31) reported similar changes in phosgene-poisoned goats.

On the other hand, this hypothesis is unlikely to apply in phosgene poisoning for the following reasons: (a) Some gassed animals developed edema with typical findings without showing the early anoxemia $(16,27)$. (b) The dogs that died in the high oxygen atmospheres with 24 hours after exposure to phosgene showed full pulmonary edema. Oxygen toxicity does not occur within this time. (c) Exposure of phosgene-poisoned rats to low oxygen tensions during the period of development of edema did not increase the mortality over that of controls in air. (d) The bronchiolar obstruction of phosgene poisoning might cause anoxia of distal alveoli (24), the severity of which would depend on the oxygen tension of the pulmonary artery blood. These tensions have been found in many instances higher than the oxygen tensions used by Drinker and associates $(20,32)$ to increase lymphatic drainage from the lung, which is not in itself proof of pulmonary edema. The peribronchial tissues, which are supplied with arterial blood, are the first areas of the lung to show edema (24), and anatomically the lymphatics are more closely related to these tissues than to the alveolar areas (33). (e) Animals (34) and men (35) have been subjected to very low oxygen tensions without evidence of pulmonary edema, and the generally accepted view that anoxia of a capillary leads to increased permeability has recently been brought up for re-examination (36). Thus it seems unlikely that alveolar anoxia significantly influences the production of edema in phosgene poisoning.

The contradiction between clinical and experimental findings may be due to the fact that oxygen therapy in phosgene poisoning in man has never been subjected to as strict a test as that described above.

\section{SUMMARY}

1. Clinical opinion has assigned oxygen therapy a critical role in the treatment of phosgene poisoning, but this evaluation has not been confirmed in experimental studies previously reported.

2. One-hundred-ten dogs were exposed to an $\mathrm{L}(\mathrm{CT}) \cdot 70$ dose of phosgene. Half were then placed in a chamber operated dynamically, in oxygen atmospheres of 95 per cent, 80 per cent and 40 per cent, until death or for 72 hours. No improvement in ultimate survival was observed. $\mathrm{Al}$ though death was delayed while the animals were in 95 per cent oxygen, ultimate survival was significantly decreased.

3. To assess the factor of oxygen poisoning in the above results, ungassed dogs were exposed to similar oxygen concentrations. Because the pulmonary damage from continuous exposure to high oxygen tensions was so similar to that of phos- 
gene poisoning, it was uncertain whether the increased mortality in the 95 per cent series was due to superimposed oxygen poisoning.

4. Because of the possibility that the edema might have been related to pulmonary anoxia, gassed rats were kept in low oxygen atmospheres (10 to 18 per cent) for the first 1 to 4 hours after gassing. This treatment did not modify the course of the poisoning, nor did it decrease survival. In some experiments survival was significantly improved.

5. The experimental findings are discussed in relation to their clinical application.

\section{BIBLIOGRAPHY}

1. Chemical Warfare Medical Committee, Report No. 10. The administration of oxygen in irritant gas poisoning. H. M. stat. off., London, October, 1918.

2. Haldane, J. S., Lung irritant gas poisoning and its sequelae. J. Roy. Army Med. Cps., 1919, 33, 494.

3. Gilchrist, H. L., The Medical Department of the United States Army in the World War, Washington, Govt. print. off., 1926, Vol. 14. Chapter 7. Symptoms and treatment.

4. Laqueur, E., and Magnus, R., Uber Kampfgasvergiftungen. V. Experimentelle und theoretische Grundlangen zur Therapie der Phosgenerkrankung. Ztschr. ges. exp. Med., 1921, 13, 200.

5. Sage, H. H., Acute phosgene poisoning; roentgen findings in the lungs; case report. Am. J. Roentgenol., 1944, 51, 9.

6. Shaw, R. E., A case of industrial phosgene gas poisoning. Univ. Leeds Med. Soc. Mag., 1941, 11, 147.

7. Steel, J. P., Phosgene poisoning; report on two cases. Lancet, 1942, 1, 316.

8. Carlisle, J. M., Pulmonary edema. J. A. M. A., 1943, 123, 947.

9. Jones, A. T., The treatment of casualties from lung irritant gases with particular reference to the use of oxygen and carbon dioxide mixture. J. Indust. Hyg. \& Toxicol., 1940, 22, 235.

10. Gerber, I., Un cas d'intoxication mortelle par le phosgène. Rev. med. Suisse Rom., 1920, 40, 356.

11. Hegler, C., Ueber eine Massenvergiftung durch Phosgengas in Hamburg. I. Klinische Beobachtungen. Deutsche med. Wchnschr., 1928, 54, 1551.

12. Longcope, W. T., and Luetscher, J. A., Jr., Personal communication, 1944.

13. Chemical Warfare Medical Committee, Report No. 1. Notes on the pathology and treatment of the effects of pulmonary irritant gases. H. M. stat. off., London, 1918.
14. Chemical Warfare Medical Committee, Report No. 7. Changes observed in the heart and circulation and the general after-effects of irritant gas poisoning. H. M. stat. off., London, 1918.

15. Prentiss, A. M., Chemicals in War. McGraw-Hill Book Co.,New York and London, 1937.

16. Underhill, F. P., The Lethal War Gases. Yale University Press, New Haven, 1920.

17. Meek, W. J., and Eyster, J. A. E., Experiments on the pathological physiology of acute phosgene poisoning. Am. J. Physiol., 1920, 51, 303.

18. Dumoulin, E., and Charlier, R., Etude experimentale de l'oxygénothérapie dans l'intoxication par phosgène. Compt. rend. Soc. de Biol., 1938, 129, 500.

19. Soulie, P., Modifications expérimentales de la résistance individuelle de certains animaux a l'action. toxique de l'oxygène. Compt. rend. Soc. de Biol., 1939, 130, 541.

20. Drinker, C. K., Pulmonary Edema and Inflammation. Harvard University Press, Cambridge, 1945.

21. Paine, J. R., Lynn, D., and Keys, A., Observations on the effects of the prolonged administration of high oxygen concentration to dogs. J. Thoracic Surg., 1941, 11, 151.

22. Bean, J. W., Effects of oxygen at increased pressure. Physiol. Rev., 1945, 25, 1.

23. Stadie, W. C., Riggs, B. C., and Haugaard, N., Oxygen poisoning. Am. J. Med. Sci., 1944, 207, 84.

24. Coman, D. R., Bruner, H. D., Horn, R. C., Jr., Friedman, M., Boche, R. D., McCarthy, M. D., Gibbon, M. H., and Schultz, J., Studies on experimental phosgene poisoning; I. The pathologic anatomy of phosgene poisoning, with special reference to the early and late phases. Am. J. Path., In Press.

25. Fisher, R. A., Statistical Methods for Research Workers. Ed. 7, Oliver and Boyd, London, 1938, p. 88-97.

26. Comroe, J. H., Jr., Dripps, R. D., Dumke, P. R., and Deming, M., Oxygen toxicity: the effect of inhalation of high concentrations of oxygen for 24 hours on normal men at sea level and at a simulated altitude of 18,000 feet. J. A. M. A., 1945, 128, 710.

27. Unpublished data.

28. Phillips, R. A., Dole, V. P., Hamilton, P. B., Emerson, K., Jr., Archibald, R. M., and Van Slyke, D. D., Effects of acute hemorrhagic and traumatic shock on renal function of dogs. Am. J. Physiol., 1946, 145, 314.

29. Shorr, E., Zweifach, B. W., and Furchgott, R. F., On the occurrence, sites and modes of origin and destruction, of principles affecting the compensatory vascular mechanisms in experimental shock. Science, 1945, 102, 489.

30. Patt, H. M., Tobias, J. M., Swift, M. N., Postel, S., and Gerard, R. W., Hemodynamics in pulmonary irritant poisoning. Am. J. Physiol., 1946, 147, 329. 
31. Barcroft, J., Anoxemia as a factor in acute gas poisoning. J. Roy. Army Med. Cps., 1921, 36, 1.

32. Warren, M. F., Peterson, D. K., and Drinker, C. K., The effects of heightened negative pressure in the chest, together with further experiments upon anoxia in increasing the flow of lung lymph. Am. J. Physiol., 1942, 137, 641.

33. Miller, W. S., The Lung. Charles C. Thomas, Springfield, Ill., 1937.
34. Van Liere, E. J., Anoxia, Its Effect on the Body. The University of Chicago Press, Chicago, 1942.

35. Gibbs, F. A., Gibbs, E. L., Lennox, W. G., and Nims, L. F., The value of carbon dioxide in counteracting the effects of low oxygen. J. Aviation Med., 1943, $14,250$.

36. Henry, J. P., Klain, I., Movitt, E., and Meehan, J. P., The effects of anoxia on the capillary permeability of the human arm. Fed. Proc., 1946, 5, 44. 